\title{
Natural variation in snow depth and snow melt timing in the High Arctic have implications for soil and plant nutrient status and vegetation composition $^{1}$
}

\author{
Mikel Moriana-Armendariz, Lennart Nilsen, and Elisabeth J. Cooper
}

\begin{abstract}
Snow cover is a key component in Arctic ecosystems and will likely be affected by changes in winter precipitation. Increased snow depth and consequent later snowmelt leads to greater microbial mineralization in winter, improving soil and vegetation nutrient status. We studied areas with naturally differing snow depths and date of snowmelt in Adventdalen, Svalbard. Soil properties, plant leaf nutrient status, and species composition along with the normalized difference vegetation index (NDVI) were compared for three snowmelt regimes (Early, Mid, and Late). We showed that (1) Late regimes (snow beds) had wetter soils, higher $\mathrm{pH}$, and leaves of Bistorta vivipara (L.) Delarbre and Salix polaris Wahlenb. had higher concentration of nutrients (nitrogen and $\delta^{15} \mathrm{~N}$ ). Little to no difference was found in soil nutrient concentrations between snowmelt regimes. (2) Late regimes had highest NDVI values, whereas those of Early and Mid regimes were similar. (3) Vegetation composition differed between Early and Late regimes, with Dryas octopetala L. and Luzula arcuata subsp. confusa (Lange) characterizing the former and Equisetum arvense L. and Eriophorum scheuchzeri Hoppe the latter. (4) Trends for plant nutrient contents were similar to those found in a nearby snow manipulation experiment. Snow distribution and time of snowmelt played an important role in determining regional environmental heterogeneity, patchiness in plant community distribution, their species composition, and plant phenology.
\end{abstract}

Key words: soil properties, plant nutrients, community composition, NDVI, Svalbard.

Résumé : La couverture neigeuse est un élément clé des écosystèmes arctiques et elle sera probablement affectée par les changements dans les précipitations hivernales. L'augmentation de l'épaisseur de la neige et la fonte plus tardive qui en résulte entraînent une plus grande minéralisation microbienne en hiver, améliorant ainsi le statut nutritif du sol et de la végétation. Les auteurs ont étudié des zones où l'épaisseur de la neige et la date de la fonte des neiges varient naturellement à Adventdalen, au Svalbard. Les propriétés du sol, le statut nutritif des feuilles des plantes et la composition en espèces ainsi que les indices de végétation (NDVI) ont été comparés pour trois régimes de fonte des neiges (précoce, moyen et tardif). Ils ont montré que (1) les régimes tardifs (lits de neige) présentaient des sols plus humides, un pH plus élevé, et les feuilles de Bistorta vivipara (L.) Delarbre et Salix polaris Wahlenb. présentaient une concentration plus élevée de nutriments

\footnotetext{
Received 7 July 2020. Accepted 25 November 2021.
}

M. Moriana-Armendariz, L. Nilsen, and E.J. Cooper. Department of Arctic and Marine Biology; Faculty of Biosciences, Fisheries and Economics; UIT- The Arctic University of Norway, Hansine Hansens veg 18, N-9037 Tromsø.

Corresponding author: Elisabeth J. Cooper (email: elisabeth.cooper@uit.no).

${ }^{1}$ This paper is part of a Special Issue entitled: Impacts of climate change on tundra ecosystems: Three decades of results from the International Tundra Experiment (ITEX).

(C) 2022 The Author(s). This work is licensed under a Creative Commons Attribution 4.0 International License (CC BY 4.0), which permits unrestricted use, distribution, and reproduction in any medium, provided the original author(s) and source are credited. 
(azote et $\delta^{15} \mathrm{~N}$ ). Peu ou pas de différence était observée dans les concentrations de nutriments du sol entre les régimes de fonte des neiges. (2) Les régimes tardifs présentaient les valeurs NDVI les plus élevées, tandis que celles des régimes précoces et moyens étaient similaires. (3) La composition de la végétation différait entre les régimes précoce et tardif, Dryas octopetala L. et Luzula arcuata subsp. confusa (Lange) caractérisant le premier régime et Equisetum arvense L. et Eriophorum scheuchzeri Hoppe le second. (4) Les tendances concernant les teneurs en éléments nutritifs des plantes étaient similaires à celles observées lors d'une expérience de manipulation de la neige menée à proximité. La distribution de la neige et le moment de la fonte des neiges ont joué un rôle important dans la détermination de l'hétérogénéité environnementale régionale, de la répartition inégale des communautés végétales, de leur composition en espèces et de leur phénologie. [Traduit par la Rédaction]

Mots-clés : propriétés du sol, nutriments des plantes, composition des communautés, NDVI, Svalbard.

\section{Introduction}

The Arctic is a system strongly bound by its abiotic conditions and, therefore, any changes in these can have dramatic effects in the ecosystem's properties including the vegetation composition. The main driver of changes in abiotic conditions is climatic change, a global phenomenon with the strongest effects in the polar areas, owing to positive feedbacks (Xu et al. 2013). One such positive feedback involves precipitation. Increased precipitation is coupled to a decrease in sea ice throughout the year (Liu et al. 2012; HoeghGuldberg et al. 2018). As more liquid water is exposed to the air, and during longer periods of time, this is expected to increase the number of days with low precipitation throughout the whole year, a phenomenon already apparent in some Arctic regions (Saha et al. 2006). During the cold season, precipitation is likely to fall as snow, and can, therefore, result in a thicker snow depth.

Snow cover creates an insulating layer that provides protection from extreme temperatures, ice formation, and herbivores, and during snowmelt it supplies water to the soil (Evans et al. 1989; Callaghan et al. 2011; Pattison and Welker 2014). Thus, changes in snow cover may alter the abiotic component of the ecosystem: warmer soils during winter, a greater water input at the beginning of the warm season, and a shift in the timing of the growing season. Arctic soil microbes have high activity in cold conditions (Mikan et al. 2002), and perform most of the mineralization during the snow-covered months (Jonasson et al. 1999; Schimel and Bennett 2004; Brooks et al. 2011). Warmer temperatures speed up the mineralization process, as well as benefit some microorganisms over others, which modify soil microbial composition and activity (Larsen et al. 2007; Zinger et al. 2009), with further consequences for the nutrient content of the soil (Lipson and Monson 1998; Grogan et al. 2004; Kreyling et al. 2008). Microbial activity may also be affected by soil water content, as during snowmelt the high water input may result in lower $\mathrm{pH}$ (Lipson et al. 2012), which alters both the microbial community composition (Zhang et al. 2016) and the activity of the community (Giesler et al. 1998). Deeper snow also enhances nutrient release from microbes during snowmelt (Buckeridge and Grogan 2010), leading to higher soil nutrient concentrations during the growing season, especially during early summer (Semenchuk et al. 2015; Mörsdorf et al. 2019).

Plants with overwintering roots take up the surplus of nutrients (especially N) during the snow-melting phases and the nutrient-release pulses (Grogan et al. 2004; Kreyling et al. 2008) and are, thus, expected to show enhanced nutrient status throughout the growing season (Walsh et al. 1997 Leffler and Welker 2013; Blok et al. 2015; Semenchuk et al. 2015; Mörsdorf et al. 2019). Moreover, the incorporation of $\mathrm{N}$ compounds influences $\mathrm{N}$ isotope composition in plants; the larger the abundance of N-rich organic material, the higher the 
microbial mineralization (Craine et al. 2009), which, in turn, releases ${ }^{15} \mathrm{~N}$-enriched $\mathrm{NH}_{4}{ }^{+}$ (Nadelhoffer et al. 1996; Yano et al. 2010). Even though mycorrhizal plants show discrimination in favour of the light isotope (Michelsen et al. 1996; Hobbie and Hobbie 2006), a high availability of ${ }^{15} \mathrm{~N}$-enriched inorganic $\mathrm{N}$ may still lead to high $\delta^{15} \mathrm{~N}$ values in these species (Leffler and Welker 2013; Blok et al. 2015; Semenchuk et al. 2015; Mörsdorf et al. 2019). Isotope concentration in plants may, therefore, be used to infer the origin of the plants' nutrients and the microbial processes involved.

Inter-specific variation in response to increased soil nutrients (Gasarch and Seastedt 2015), temperature-enhanced respiration (Cooper 2004; Morgner et al. 2010; Semenchuk et al. 2016b) or spring water-logging may affect vegetation composition (Gasarch and Seastedt 2015; Park et al. 2018; Cooper et al. 2019) through species-specific responses in growth rates and size (Rumpf et al. 2014), and altered flowering phenology and interaction with pollinators (Lambert et al. 2010; Gillespie et al. 2016). These effects are further influenced by the late start of the growing season, which may result in reduced development and lower reproductive success (Cooper et al. 2011; Semenchuk et al. 2016a), with repercussions to the $\mathrm{CO}_{2}$ balance of the ecosystem (Aurela et al 2004) Snow depth and duration is highly important in determining species distribution of ecosystems characterized by seasonal snow cover, such as arctic tundra (Niittynen and Luoto 2018), and any changes in snow cover are therefore likely to affect diversity (Niittynen et al. 2018). Above-ground plant productivity and phenology can be studied using the normalized difference vegetation index (NDVI) (Tucker 1979; Myneni et al. 1995), as it correlates with total plant cover (Jordan 1969; Laidler et al. 2008; Cooper et al. 2019) and, as such, varies throughout the growing season (Jia et al. 2004; Gamon et al. 2013; Anderson et al. 2016). Differences in NDVI between areas might be due to an earlier or later start of growth, and this may, in turn, indicate vegetation responses to the snow regime.

One of the most common methods of studying the effect of snow on vegetation has been experimental manipulation, such as the establishment of snow fences, which disturb wind circulation and drive snow accumulation (Walker et al. 1999; Buckeridge and Grogan 2008; Morgner et al. 2010; Cooper et al. 2019). However, studies within natural gradients can inform about the range of snow depths and melting dates found in an area, and details of the habitats contained within. In the Arctic, maximum snow depth is defined by microtopography, as wind redistributes snow filling up gullies and snow accumulates around prominent objects (Liston and Sturm 1998). Moreover, melt timing is constrained by aspect (and therefore amount of incoming radiation) and snow depth (deeper snow takes longer to melt) as well as local air temperature and precipitation. Comparison of natural gradients with experimental studies are helpful to show how realistic the experimental data may be and how much it can be interpolated over a wider spatial area.

To study the role of snow depth and associated snow melt timing due to microtopographic variation only, we performed a pilot study in a relatively flat area in Adventdalen, Svalbard with a standard aspect. We investigated soil properties, plant nutrient status, and species presence in areas of naturally differing snow depths and date of snowmelt. Three snowmelt regimes (Early, Mid, and Late melt) were delimited to test the following hypotheses: (1) regimes with deeper snow and later snowmelt have (a) wetter soils, and higher concentration of $(b)$ soil nutrients and $(c)$ plant nutrients in mid-summer; (2) vegetation composition differs between snow regimes; and (3) late melting snowbeds with deeper snow and increased nutrients have highest NDVI values in mid-summer. Furthermore, (4) we related our data obtained in 2015 from a natural system to the response of soil and plants in a nearby snow manipulation experiment (Mörsdorf et al. 2019), performed during the same summer. 
Fig. 1. Location of the study site in Adventdalen, in the Svalbard archipelago, approximately $15 \mathrm{~km}$ from Longyearbyen. Distribution of the Early (triangle), Mid (circle) and Late (square) melting plots within the study site. Note the gullies where snow accumulates and where most of the Late plots are located. A line has been drawn to separate polygons 2 and 3. Due to the scale the line has been drawn over one of the plots, which belongs to polygon 2 .

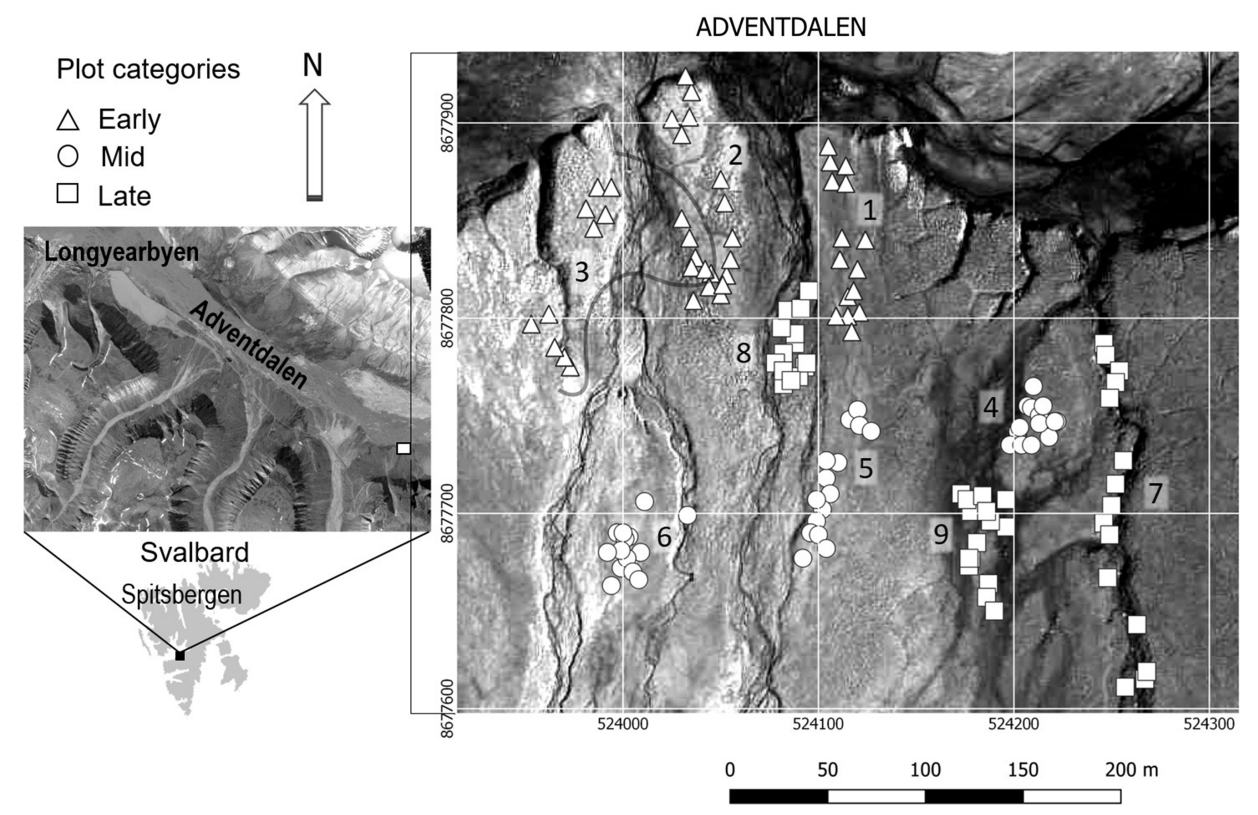

\section{Materials and Methods}

\section{Study site}

The study was performed in Adventdalen, Western Spitsbergen, Svalbard, Norway $\left.78^{\circ} 10^{\prime} \mathrm{N}, 16^{\circ} 04^{\prime} \mathrm{E}\right)$. The closest meteorological station is located at Svalbard airport, roughly $15 \mathrm{~km}$ away. Average temperature for the $1971-2000$ period was $-5.9{ }^{\circ} \mathrm{C}$, with winter temperature (December-January-February) of $-13.9{ }^{\circ} \mathrm{C}$ and summer temperature (JuneJuly-August) of $4.5^{\circ} \mathrm{C}$; and the annual precipitation was $200 \mathrm{~mm}$ (Norwegian Center for Climate Services 2019). Parent rocks consist of basic calcareous sand, silt, and shale originated during the Mesozoic Era (Tolgensbakk et al. 2000). Soils in Adventdalen are poorly developed and moderately acidic (5-6.5) with a thin O-horizon (usually $2 \mathrm{~cm}$, ranges from 0.2 to $6 \mathrm{~cm}$ ) of slightly decomposed organic material and live plant roots, a dark-brown A horizon of an average thickness of $2 \mathrm{~cm}(1-5 \mathrm{~cm})$, and a B/C horizon of grey silt (Strebel et al. 2010). The concentration of soil organic carbon and total nitrogen are highest at the top and decrease through the soil profile. Live plant roots extend to around $45 \mathrm{~cm}$ deep. The vegetation is classified as part of the middle Arctic tundra zone (Elvebakk 2005), with Cassiope tetragona (L.) D.Don, and Dryas octopetala L., abundant Salix polaris Wahlenb. and Bistorta vivipara (L.) Delarbre, Luzula arcuata subsp. confusa (Lange) and bryophytes common throughout the area (see Cooper et al. 2019 for more details).

\section{Data gathering}

The study site covers $0.23 \mathrm{~km}^{2}$ and is relatively flat, gently sloping up towards the steep hills to the south, and is dissected by streams with gullies 1-3 m deep (Fig. 1). Microtopography determines snow accumulation; three snow melt regimes were 
Fig. 2. Photos of the study site in Adventdalen, Svalbard, taken by a camera standing on a nearby hill during 2014. (A) On 21 May 2014 all Early plots were snow-free; (B) On 29 May 2014 the Mid plots were also snow-free; (C) On 22 June 2014 the whole study area, including the Late plots, was snow-free. In D (same photo as $\mathrm{C}$ ) we present all polygons together. In $\mathrm{B}$ the location of the temperature loggers is shown by two small ellipses marked with a $\mathrm{W}$ (west location) and an $\mathrm{E}$ (east location).

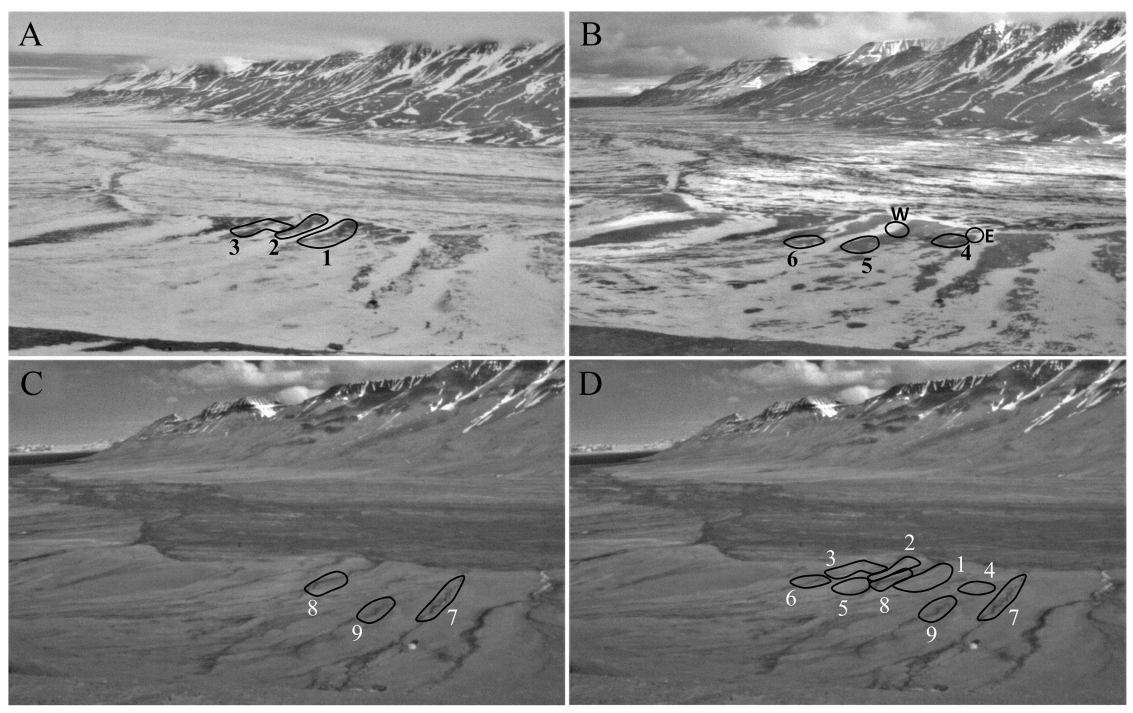

identified (termed "Early", "Mid", and "Late") using daily monitoring photos taken in 2014 by a camera mounted on an adjacent hillside. Early (Fig. 2A): windblown ridges with shallow snow cover in winter (approximately 7-15 cm) became snow-free by 21 May. Mid (Fig. 2B): slightly lower areas that accumulated approximately $20-40 \mathrm{~cm}$ snow and melted out by 29 May. Late: on the sides of gullies, accumulated approximately 1-2 $\mathrm{m}$ snow, and became snow-free by 22 June (Fig. 2C). Nine polygons were established from the 2014 hillside monitoring photos (three polygons within each snowmelt regime (Fig. 1)).

Fieldwork was carried out on 15-20 July 2015. In each polygon 15 plots of $0.12 \mathrm{~m}^{2}$ $(35 \times 35 \mathrm{~cm})$ were distributed at approximately $10 \mathrm{~m}$ distance (linear transects or clustered arrangements of plots depending on topography). In all plots soil moisture was measured at its centre using a Theta ML $2 \times$ Probe (Delta-T Devices, Cambridge, UK); and the NDVI was recorded keeping the handheld Greenseeker sensor (Trimble AG Field Solutions, Sunnyvale, California, USA) approximately $90 \mathrm{~cm}$ over the plot and parallel to the ground, thus scanning an oval-shaped area of roughly $38 \mathrm{~cm}$ width. The Greenseeker sensor calculated the NDVI based on reflected red and near infra-red radiation, obtaining values between -1 and +1 . Five plots were selected randomly from each polygon for soil and plant sampling. Soil samples were extracted using a $3 \mathrm{~cm}$ diameter soil corer and transported to the lab on the same day, where they were stored in a fridge at $4{ }^{\circ} \mathrm{C}$ until further processing was conducted (a maximum delay of one week). In those same plots, leaf material was collected for nutrient analysis, choosing six of the most commonly occurring plant species: Alopecurus ovatus Knapp, Bistorta vivipara (L.) Delarbre, Dryas octopetala L., Luzula arcuata subsp. confusa Lange, Poa arctica R.Br. and Salix polaris Wahlenb. (International Plant Names Index 2020). In the remaining 10 plots the presence/absence of these six species and Equisetum arvense L. and Eriophorum scheuchzeri Hoppe was recorded. 
A summary of the number of plots used for the various analyses is included in Supplementary Table $S 1^{2}$.

To have a reference for how snow regimes differed in soil temperature during the cold season, six temperatures loggers (Tinytag data loggers model TGP-4020; Gemini Data Loggers, Chichester, UK) were located near the study area in October 2019: two in Early snowmelt, two in Mid, and two in Late. The loggers were located within the side of the stream gullies (see Fig. 2A), with Early at the top, Mid approximately one metre lower, and Late at the bottom (two metres lower). The snow regimes were, thus, exposed to different snow depths (deepest at the bottom), comparable with those found in the snow fence experiment (Mörsdorf et al. 2019). The loggers recorded near soil-surface temperature hourly, and were later recovered in mid-July 2020 (except one logger from the Late snow regime, which was not found). Daily average temperatures were calculated for each snow regime.

\section{Nutrient analyses}

From each soil sample $3 \mathrm{~g}$ fresh weight of soil were suspended in $30 \mathrm{~mL}$ of distilled water at room temperature and then shaken for two hours. Extracts were transferred into $20 \mathrm{~mL}$ plastic vials using $0.45 \mu \mathrm{m}$ syringe filters, and frozen at $-18{ }^{\circ} \mathrm{C}$ until further analysis. The extracts were analysed for $\mathrm{pH}$, as well as concentration of nitrogen from dissolved organic nitrogen (DON), ammonium $\left(\mathrm{NH}_{4}{ }^{+}\right)$, and nitrate $\left(\mathrm{NO}_{3}{ }^{-}\right)$using a flow injection analyser (Fiastar 5000, FOSS Analytical, Hilleroed, Denmark). The ratio of dry weight to fresh weight was used to standardize the values into $\mu$ g nutrient per g dry weight soil.

Plant leaf samples were ground until they became a homogeneous powder. For S. polaris this was done with a mortar and pestle, whereas for the rest of the species a grinding mill was used (Retsch Mixer Mill, Retsch GmbH, Haan, Germany). Two mg of each sample was then added to tin capsules and analysed for $\mathrm{C}$ and $\mathrm{N}$ concentrations, as well as $\delta^{13} \mathrm{C}$ and $\delta^{15} \mathrm{~N}$ isotope signatures, using IRMS (CE $1110 \mathrm{EA}$ ), which was coupled in continuous flow mode to a Finnigan MAT Delta PLUS isotope ratio mass spectrometer (Thermo Scientific, Bremen, Germany).

The soil and plant samples were prepared and analysed using the same method and lab and concurrent with those from the nearby snow manipulation experiment (Mörsdorf et al. 2019), to enable later comparison.

\section{Statistical analyses}

All analyses were performed in $\mathrm{R}$ ( $\mathrm{R}$ Core Team 2019). Linear mixed effect models were used to analyse differences in soil moisture, $\mathrm{pH}$, and nutrient concentration between snowmelt regimes, as well as for NDVI. The function lme from the nlme package (Pinheiro et al. 2019) was used for modelling: the four variables of study were fitted as dependent variables, snowmelt regime (Early, Mid, and Late) as independent variable, and specific polygon (1 to 9) as random factor. In some cases, a weighted factor had to be applied to account for the difference in variance between areas (heteroscedasticity). Moreover, spatial autocorrelation was checked in all the analyses, as it could affect our results. The same procedure was used for plant nutrient concentrations but, as plant species vary in their nutrient values and may respond differently to variations in snow cover (Rumpf et al. 2014; Mörsdorf et al. 2019), each species was modelled separately. Bistorta vivipara and $S$. polaris were common in all snowmelt regimes, and, therefore, differences between Early, Mid, and Late could be established. The other three species were present (in more than one plot) only in two of the regimes: D. octopetala and L. arcuata in Early and Mid, P. arctica in Mid and Late.

\footnotetext{
${ }^{2}$ Supplementary data are available with the article at https://doi.org/10.1139/as-2020-0025.
} 
Fig. 3. Daily soil temperature at each snow regime (Early, Mid, and Late) during the 2019-2020 cold season and beginning of growing season. Average of two temperature loggers at Early, two at Mid, and one at Late.

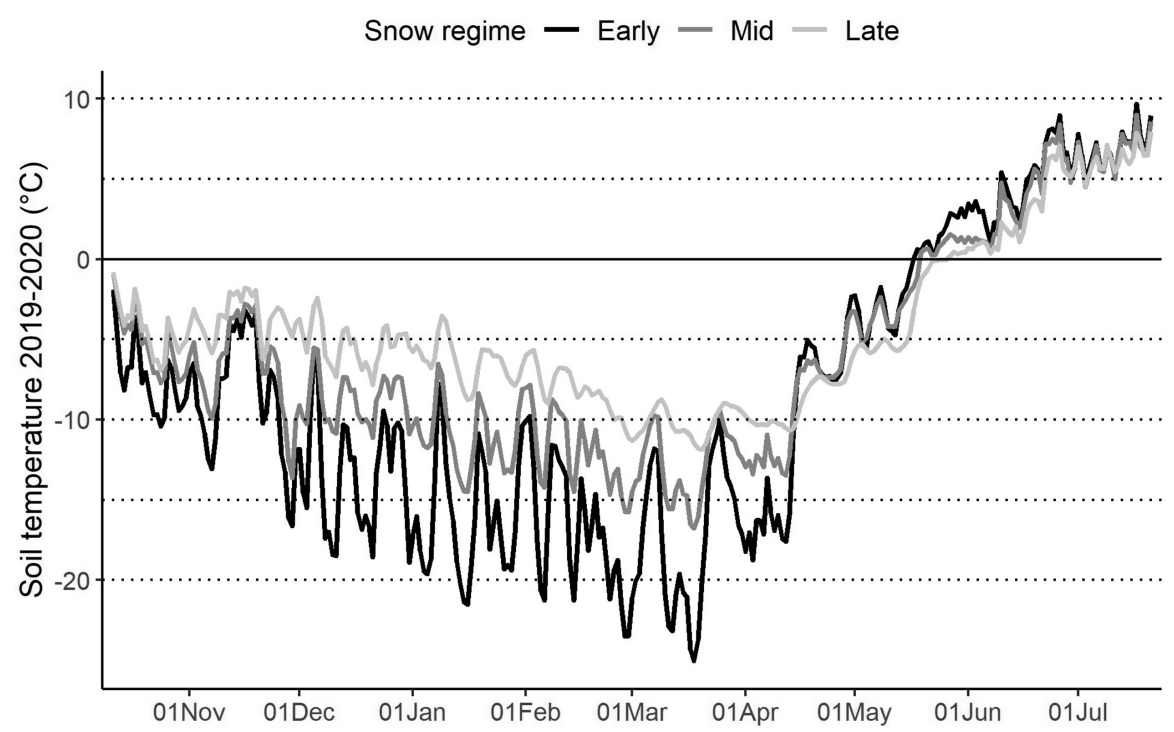

For the distribution of plant species, the non-metric multidimensional scaling (NMDS) ordination method was used, which is a very flexible technique that does not assume any special response from the data (linear, unimodal, etc). From the package vegan in $R$ (Oksanen et al. 2018), the formula metaMDS was used, which, in turn, is based upon the isoMDS function. Due to the absence/presence of the data the Jaccard index was used to create the distance matrix. The formula coerces all points into the desired number of dimensions (two in this study), while keeping the order (ranks) of the distance between points in the original space. The greatest variance is explained by the first axis, but this aspect is not quantified as in other multidimensional techniques. The difference between the original distances and those newly created is called stress and serves as measurement of goodness of fit. The model was run 1000 times from random start positions to avoid local optima and find the global one. NMDS analysis was run considering only those plots for which complete species data were available ( 30 plots per regime). Arrows were added to the NMDS plot to represent soil moisture and NDVI: the angle of the arrows indicates the correlation to the axes (horizontal correlated to axis 1, vertical to axis 2), and the length the importance of the variable (longer arrows indicate more important variables).

\section{Results}

\section{Soil characteristics}

During the 2019-2020 cold season, soil temperature was higher in the Late regime than in Mid, which, in turn, was warmer than the Early regime (Fig. 3). At the beginning of the warm season (end of May - beginning of June) the pattern was the opposite, as areas where the snow had melted were warmer than areas still under the snow (temperatures increased above $0{ }^{\circ} \mathrm{C}$ first in Early, then in Mid, and finally in Late).

Average soil moisture in the Early regime was 31\%, whereas in Late it was significantly higher (moisture $65 \%, p=0.024$ ). The Mid regime had an intermediate value $(48 \%$ ) but did not differ significantly from Early or Late (Fig. 4A, Supplementary Table S2 ${ }^{2}$ ). Soil pH was 
Fig. 4. (A) Estimated soil moisture and (F) NDVI for the different snowmelt regimes; as well as (B) soil pH and (C) concentration of nitrogen from dissolved organic nitrogen (DON-N), (D) ammonium $\left(\mathrm{NH}_{4}{ }^{+}-\mathrm{N}\right)$ and (E) nitrate $\left(\mathrm{NO}_{3}-\mathrm{N}\right)$ extracted from $0-5 \mathrm{~cm}$ soil cores. Error bars represent $95 \% \mathrm{CI}$. Snowmelt regimes with the same letter do not differ at a 5\% significance level (only those cases where differences were found have been labelled with letters).

A

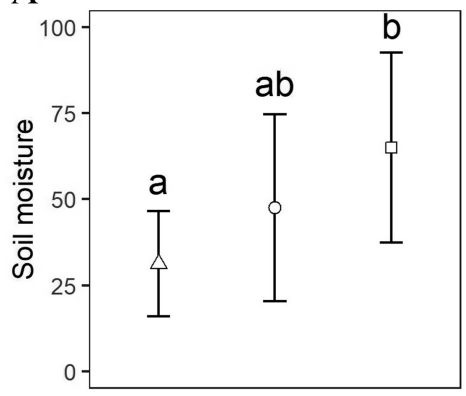

$\mathrm{D}$

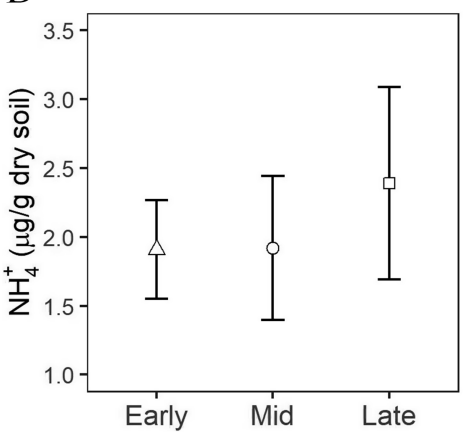

B

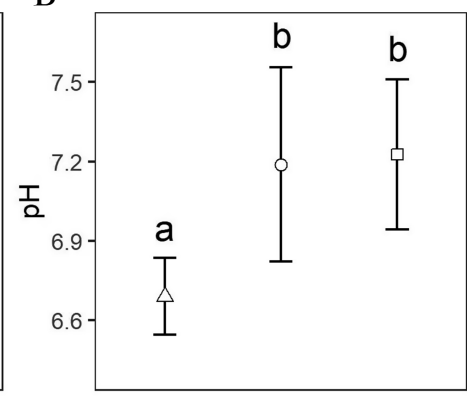

$\mathrm{E}$

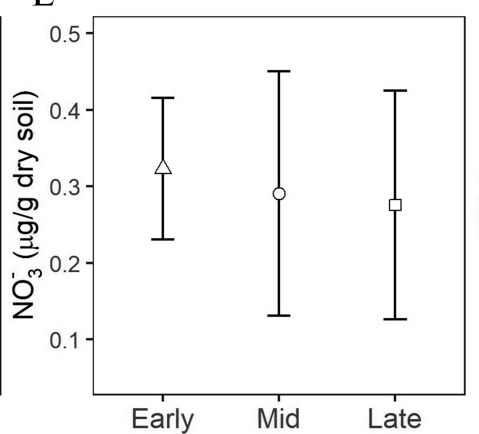

$\mathrm{C}$

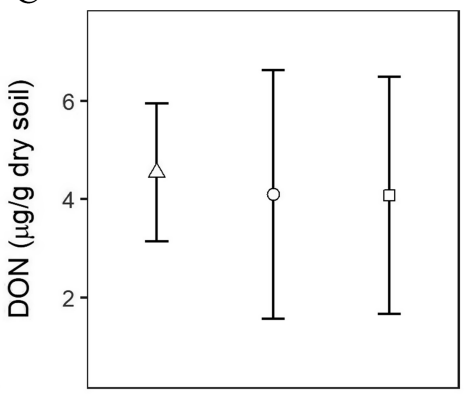

$\mathrm{F}$

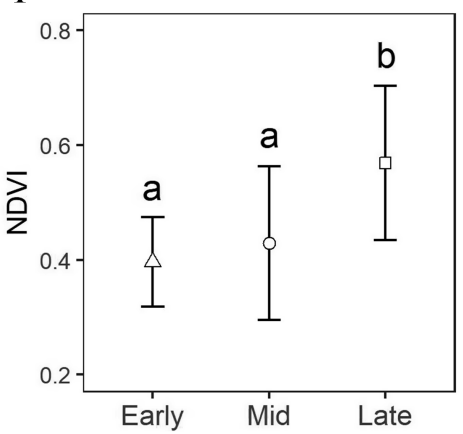

6.7 in Early, significantly lower than both Mid $(p=0.017)$ and Late $(p=0.005)$ regimes (Fig. 4B, Supplementary Table S2 ${ }^{2}$ ).

Soil nutrient concentrations did not differ between snowmelt regimes (Fig. 4C, D, and E, Supplementary Table $\mathrm{S2}^{2}$ ). Concentration of DON was $4.5 \mu \mathrm{g} / \mathrm{g}$ of dry soil in Early, and insignificantly lower in Mid and Late $(4.1 \mu \mathrm{g} / \mathrm{g})$. Nitrate showed a very similar pattern, where Early $\left(0.32 \mu \mathrm{g} \mathrm{NO}_{3}{ }^{-} / \mathrm{g}\right)$ was slightly, but insignificantly, higher than Mid $(0.29 \mu \mathrm{g} / \mathrm{g})$ and Late $(0.28 \mu \mathrm{g} / \mathrm{g})$. Ammonium concentration was $1.9 \mu \mathrm{g} \mathrm{NH}{ }_{4}{ }^{+} / \mathrm{g}$ of dry soil of both Early and Mid, and although Late was $26 \%$ greater $(2.4 \mu \mathrm{g} / \mathrm{g})$ it was not significantly different $(p=0.143)$.

\section{Leaf nutrient concentrations}

Leaf nitrogen followed similar patterns in B. vivipara and S. polaris, with no differences between Early and Mid and higher values in Late (Fig. 5, Supplementary Table $\mathrm{S}^{2}$ ). Nitrogen in B. vivipara leaves was $17 \%$ greater in Late than Early (3.6\% in respect to $3.1 \%$, $p=0.056)$, and in $S$. polaris $21 \%$, (3.1\% in respect to $2.6 \%, p=0.042)$. The same pattern was found for $\delta^{15} \mathrm{~N}$. B. vivipara had higher values in Late than in Early $(-2.7 \%$ ond $-4.8 \%$ respectively, $p=0.049$ ) and so did $S$. polaris $(-1.4 \%$ and $-4.7 \%$ respectively, $p=0.042)$. Carbon concentration, $\mathrm{C} / \mathrm{N}$ ratio, and $\delta^{13} \mathrm{C}$ did not vary between snowmelt regimes (Fig. 5, Supplementary Table $\mathrm{S3}^{2}$ ).

The other species (D. octopetala, L. arcuata and P. arctica) did not show differences in any of the nutrients studied (Fig. 5, Supplementary Table $S 3^{2}$ ), although only samples from two snowmelt regimes could be used in all three cases and, therefore, Early and Late could not be compared. 
Fig. 5. Observed values of (A) nitrogen, (B) carbon, (C) $\delta^{15} \mathrm{~N}$, (D) $\delta^{13} \mathrm{C}$ and (E) C/N ratio from leaves of Bistorta vivipara, Dryas octopetala, Luzula arcuata, Poa arctica, and Salix polaris; for three naturally occurring snowmelt regimes sampled on 15-20 July 2015. Error bars represent 95\% CI. Snowmelt regimes with the same letter do not differ at a 5\% significance level (only those cases where differences were found have been labelled with letters).

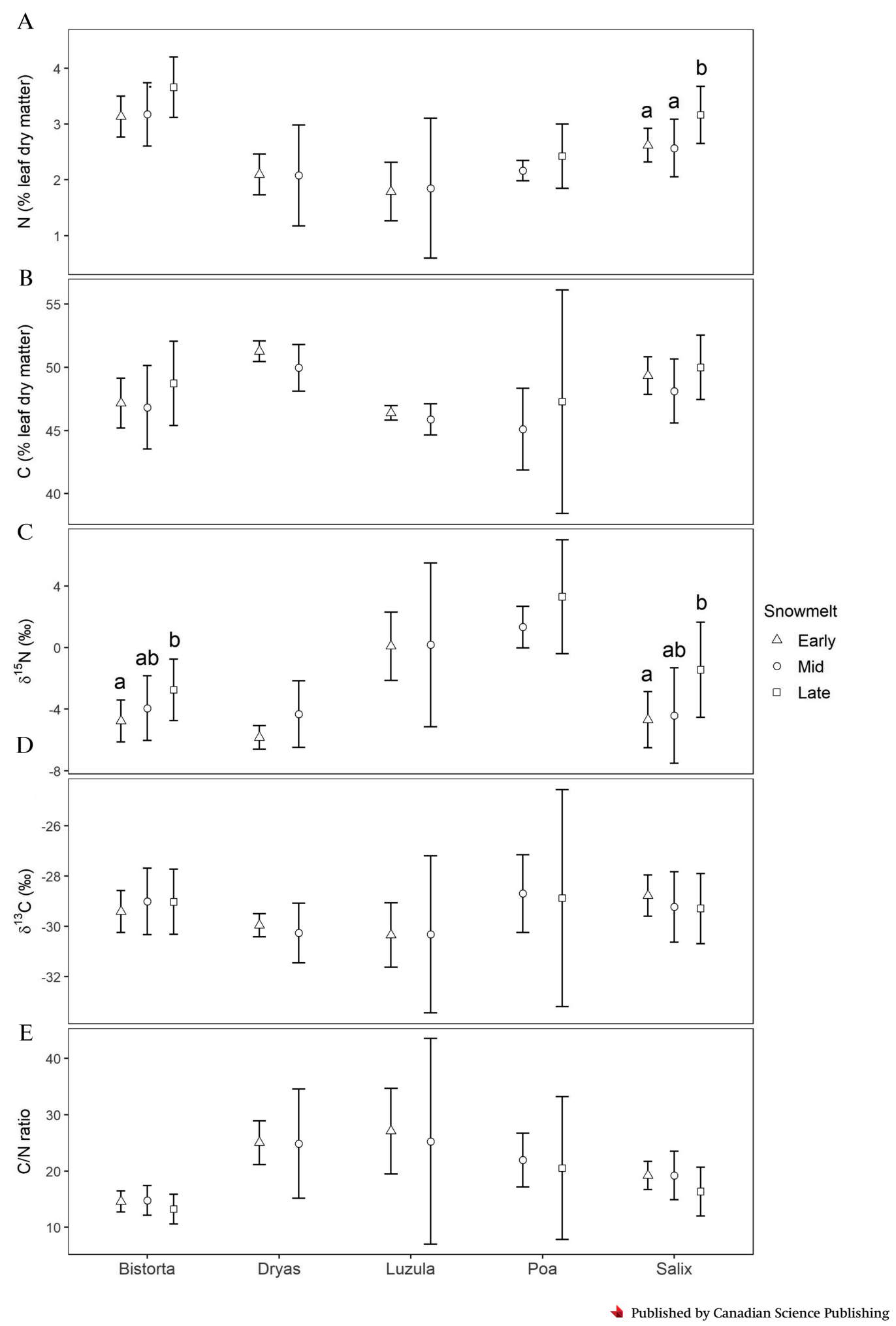


Fig. 6. Graphical display of the non-metric multidimensional scaling (NMDS) analysis, showing the different plots and the average values for the plant species (the midpoint of the word represents the average value of a species). Convex hulls have been drawn for the different snow regimes. Furthermore, the correlation of soil moisture and normalized difference vegetation index (NDVI) with the NMDS space is graphically presented by means of arrows.

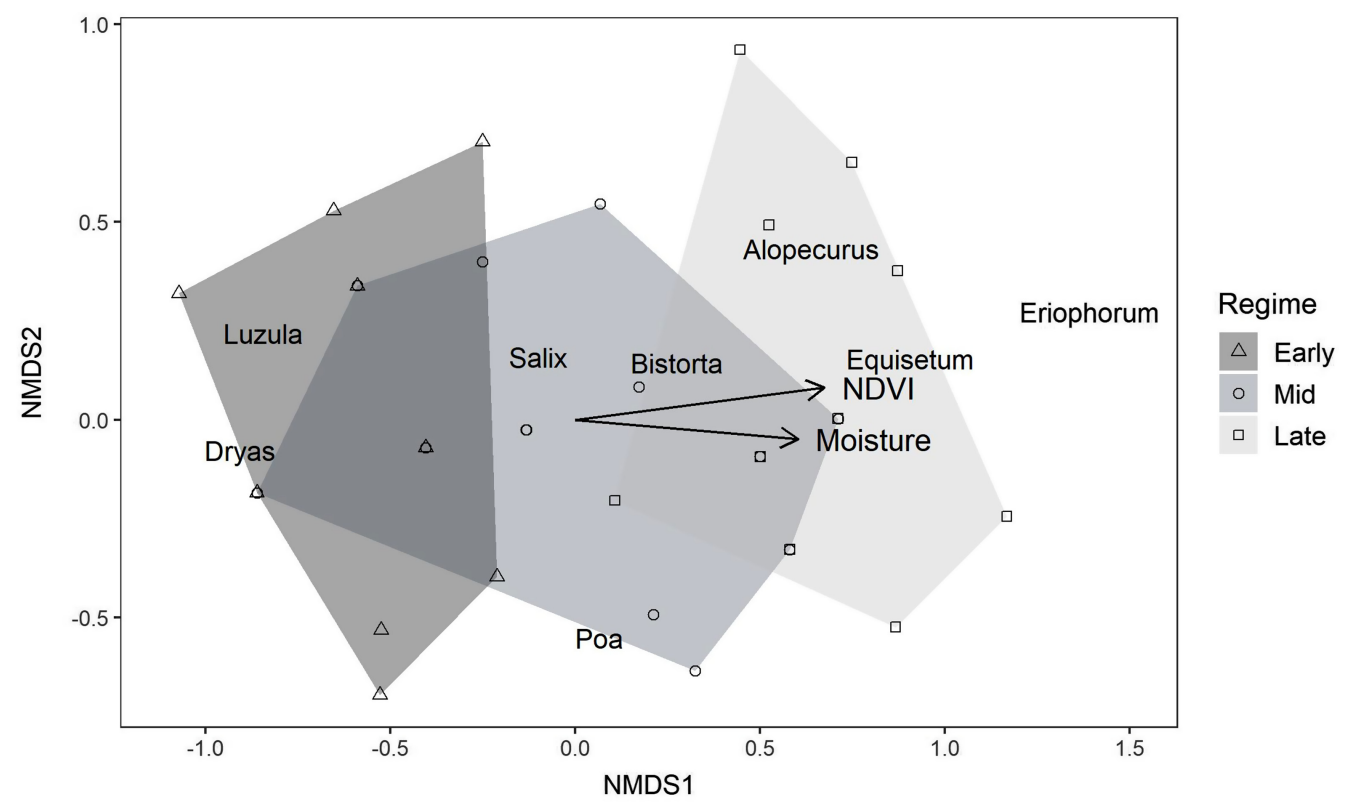

NDVI, soil moisture, and species distribution

The NDVI data show that Late plots were significantly greener than Early $(p=0.020)$ and Mid plots $(p=0.041)$ at time of sampling (Fig. 4F, Supplementary Table S2 ${ }^{2}$ ). Early had an NDVI value of 0.40 , Mid of 0.43 , and Late of 0.57 .

The NMDS analysis had a stress of 0.063 , meaning the difference between the original distances and those newly created was very small and the NMDS accurately represented the original distribution (Clarke and Warwick 1994). NDVI and soil moisture were clearly correlated with the first NMDS1 axis (Fig. 6), with positive (higher) values to the right of the figure. Early and Late regimes showed differences in their species composition, as they were distributed along the first axis (with Late to the right), whereas Mid had an intermediate species composition. This illustrates that the Late regime had the wettest soil and the greatest NDVI values. The second axis (NMDS2) did not seem to be related to the snowmelt regimes.

Dryas octopetala and L. arcuata were located towards the left of the figure (Fig. 6), whereas Equisetum arvense and Eriophorum scheuchzeri were more to the right. This suggests that $D$. octopetala and L. arcuata were found more commonly in the drier, low-NDVI Early plots, whereas Equisetum arvense and Eriophorum scheuchzeri were found in the wet, high-NDVI Late plots.

\section{Comparison between this gradient study and a nearby experimental study}

Values for this current study (15-20 July 2015) and those reported in the experimental study (Mörsdorf et al. 2019) for 13-14 July 2015 were compared in Fig. 7 and Supplementary Table $S 4^{2}$. Values were mostly within a similar range. Trends of increasing plant leaf nutrients with increasing snow were visible in both studies. This current study, 
Fig. 7. Comparison of estimated values between the current gradient study (Grd, based on snowmelt timing) and the experimental study by Mörsdorf et al. (2019) (Exp, based on snow depth). (A) Soil moisture is shown in \% of soil water capacity. (B) Concentrations of nitrogen in the form of dissolved organic nitrogen (DON-N), (C) ammonium $\left(\mathrm{NH}^{+}{ }^{+} \mathrm{N}\right)$ and $(\mathrm{D})$ nitrate $\left(\mathrm{NO}_{3}{ }^{-} \cdot \mathrm{N}\right)$ are shown in $\mu \mathrm{g} \mathrm{N}$ per $\mathrm{g}$ of dry soil. Concentrations of $\mathrm{N}$ in (E) Bistorta vivipara and $(\mathrm{F})$ Salix polaris leaves are shown in \% of leaf dry matter. $\delta^{15} \mathrm{~N}$ of $(\mathrm{G})$ B. vivipara and $(\mathrm{H})$ S. polaris leaves is shown in \%.

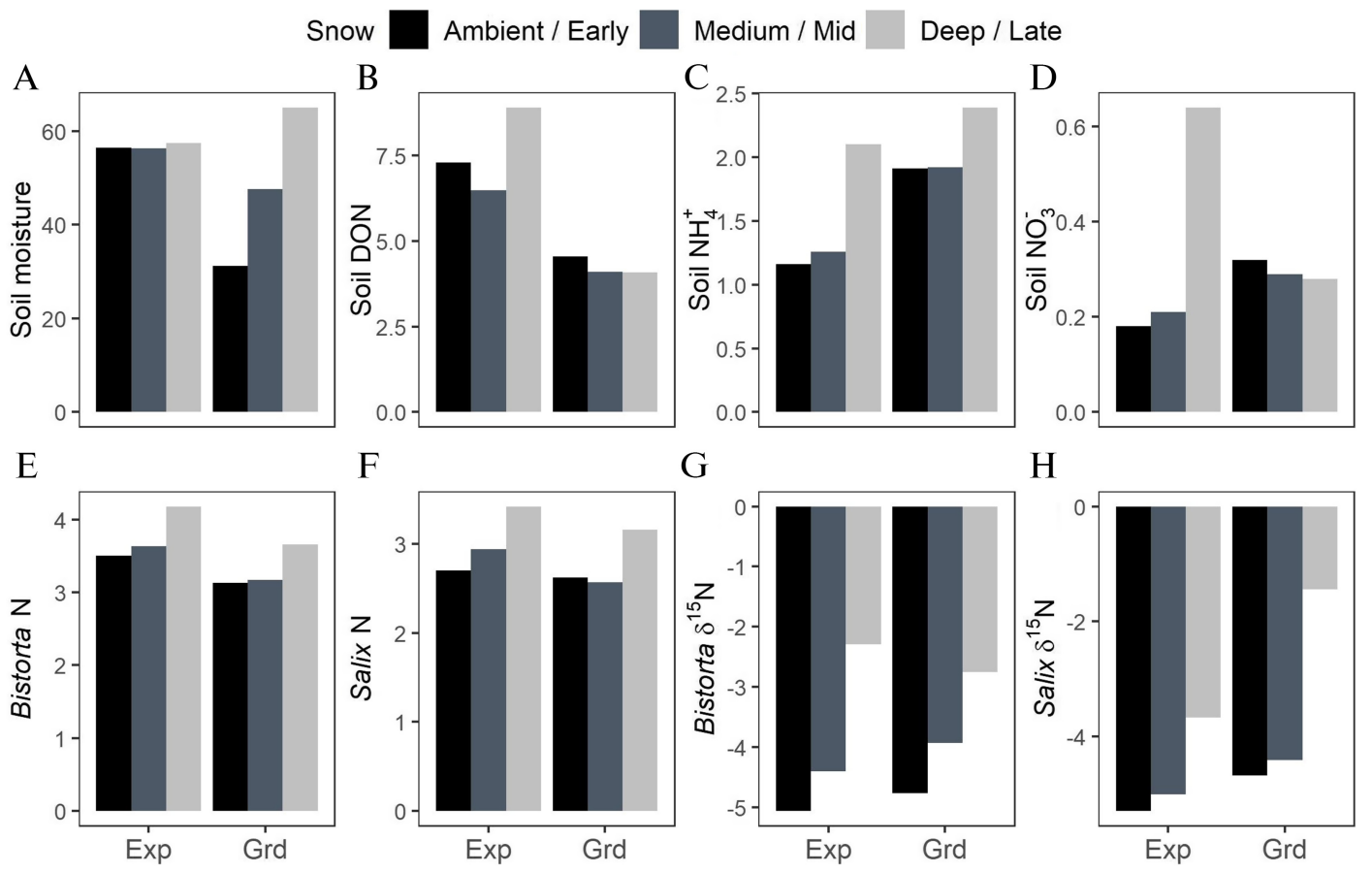

however, differs from the experimental study in that it did not show clear increases in soil nutrients with increased snow.

\section{Discussion}

\section{Soil characteristics}

Even though the snow regimes in the current study were established according to date of snow melt timing, they showed differences in temperature (Fig. 3) similar to those found in the nearby snow fence experiment (Semenchuk et al. 2015; Mörsdorf et al. 2019), where a thicker layer of snow led to warmer winter soil temperatures, and was established as one of the drivers behind the soil and plant nutrient differences found between different snow depth regimes.

In Arctic regions precipitation is usually low, and snowmelt is the most important input of water for the growing season, with high moisture levels recorded during the weeks following snowmelt (Buckeridge and Grogan 2010; DeMarco et al. 2011; Cooper et al. 2011). Both winter winds and topography determine snow distribution (Liston and Sturm 1998). Our Late melting plots were located on the sides of gullies, common features in the Arctic that efficiently carry water from the surrounding hills towards the stream channels (Walker et al. 1989). Snow deposition and soil moisture is generally higher in these features (Kane et al. 1991; Zhang et al. 2000). There is a thicker layer of silt and fine sand in the depressions along the streams as fine soil is windblown from the more elevated plateaux. This also implicates their ability to store more water and for longer periods than moraine 
soil or stone-rich alluvial river fans with better drainage. As expected (Hypothesis 1a), our mid-season soil moisture values were highest in our Late regime. In the nearby snow fence experiment (Mörsdorf et al. 2019, see Supplementary Figure $S 1^{2}$ for relative location) soil moisture was much higher for the enhanced snow treatments than for ambient conditions soon after snowmelt, but these differences were no longer apparent by mid-season. Experimentally enhanced snow treatments had soil moisture values mid-way between those of our Mid and our Late (Fig. 7, Supplementary Table $S 4^{2}$ ).

In contrast to our hypothesis (Hypothesis $1 \mathrm{~b}$ ), mid-season soil nutrients showed little variation between regimes, with only slightly higher $\mathrm{NH}_{4}{ }^{+}$in later melting areas. This contrasts with those in the nearby snow accumulation experiment in the same valley. After 6 years of continuous snow depth enhancement, Semenchuk et al. (2015) found an increase in $\mathrm{NH}_{4}{ }^{+}$and $\mathrm{NO}_{3}{ }^{-}$under deep snow, and after 9 years Mörsdorf et al. (2019) showed an increase in all three variables, $\mathrm{DON}, \mathrm{NH}_{4}{ }^{+}$, and $\mathrm{NO}_{3}{ }^{-}$. Our values are very different from those in the latter article when comparing similar snow regimes: Ambient with Early, Medium with Mid, and Deep with Late. Our DON was between 37\% and 54\% lower, $\mathrm{NH}_{4}{ }^{+}$ between $14 \%$ and $64 \%$ greater, and $\mathrm{NO}_{3}{ }^{-}$was lower in Ambient and Medium but higher in Deep (Fig. 7, Supplementary Table S4 ${ }^{2}$ ). A similar trend of higher soil nutrient concentration was obtained by Schimel et al. (2004), where areas under a deeper snowpack experienced greatly enhanced $\mathrm{NH}_{4}{ }^{+}$and $\mathrm{NO}_{3}{ }^{-}$concentrations from the end of winter extending throughout the growing season and far into September.

Our soil nutrient trends are more like those found by Buckeridge and Grogan (2008, 2010), Koller and Phoenix (2017) and Darrouzet-Nardi et al. (2019), although it is important to note that in those studies the deeper snow increased nutrient concentration in late winter. Thermal insulation due to thicker snow enhanced the decomposition of organic matter, followed by strong microbial immobilization (Nobrega and Grogan 2007; Buckeridge and Grogan 2008). However, microbial and plant communities took up the enhanced nutrient influx soon after snowmelt, leaving little trace of this later in the season (Buckeridge and Grogan 2010; Koller and Phoenix 2017).

It is, therefore, highly important to consider the seasonality of nutrient dynamics, especially when sampling is only carried out once during the summer, as in the present study. Mörsdorf et al. (2019) showed that DON dropped immediately after snowmelt, followed by a constant increase during the growing season; and if we equate our Early regime (melted by 21 May) to their Ambient regime (melted by 23 May), our samples were taken two weeks after the increase in DON began in Ambient, suggesting that our Late plots were still in the declining phase and our Early plots in the increasing phase at this time and, thus, similar values could be expected. The concentrations of ammonium and nitrate in the experiment increased most strongly later in the season (from 14 July Mörsdorf et al. 2019), simultaneously with the dates of our sample collection, which indicates that our Early, Mid, and Late plots were still in their low concentration states prior to the late summer increase. Further study, considering more sampling dates during the year, would be necessary to establish the nutrient dynamics in our study plots. Furthermore, in a study in Adventdalen, Bardgett et al. (2007) found striking differences between dry and wet meadow, suggesting that other factors, such as wetter soil conditions, might constrain biological activity.

Another possible explanation of the lack of snowmelt regime on soil nutrient concentrations is soil pH, as the values in Early (6.7) were greater than the highest measurements in the experiment, both those reported by Semenchuk et al. (2015) and Mörsdorf et al. (2019) (under than 6.5 in both cases). Additionally, both Mid and Late showed significantly higher values (around 7.2). Areas with high water content or even flooding (as our gullies) generally have low levels of dissolved oxygen and high $\mathrm{pH}$ (Lipson et al. 2012), conditions that favour 
denitrification, increasing $\mathrm{N}$ release in gaseous form (Grogan et al. 2004; Sharma et al. 2006). Moreover, $\mathrm{pH}$ also affects the microbial community (Eskelinen et al. 2009; Siciliano et al. 2014) and it affects enzymatic reactions in the soil (Stark et al. 2014). Increased pH has been found to reduce the potential activity of $\beta$-glucosidase, an enzyme synthesized for cellulose degradation, in turn, reducing the decomposition of plant material and slowing soil nutrient cycles (Stark et al. 2014). Close to Advent River, the plateaux and alluvial river fan deposit overlie marine sediments. Some of the smaller rivers may erode into these marine and highly alkaline substrates, and this should be further investigated. Future research should help discern the relative importance of snowmelt timing and $\mathrm{pH}$ for soil nutrient cycling.

\section{Leaf nutrient concentration}

Hypothesis 1c could be partly accepted, as leaf nutrients of two of the species were affected by snowmelt regime. Leaves from $S$. polaris had significantly higher values of $\mathrm{N}$ in Late than in Early and Mid regimes, as was the case for enhanced snow in studies by Semenchuk et al. (2015) and Mörsdorf et al. (2019) (Fig. 7, see Supplementary Table S42). These values were similar in Early/Ambient among the three studies (2.62\% in the present work, $2.84 \%$ and $2.70 \%$ in the experimental studies by Semenchuk et al. (2015) and Mörsdorf et al. (2019)), although in Late/Deep they differed somewhat (3.16\% to $3.87 \%$ and $3.42 \%$, respectively), as we found a smaller difference between regimes: Late was $21 \%$ greater than Early, whereas Deep was 36\% higher than Ambient in Semenchuk et al. (2015) and 27\% in Mörsdorf et al. (2019). A trend towards increased nutrients in Late was also found in leaves of B. vivipara. Plants growing in Late had $17 \%$ greater $\mathrm{N}$ concentration than those in Early (3.66\% and 3.13\%, respectively), comparable with the $19 \%$ increase due to snow accumulation observed by Mörsdorf et al. (2019) (from 3.50\% in Ambient to 4.18\% in Deep). Insufficient sampling in this pilot study most likely contributed to lack of clear regime differences for the other species, all of which responded to deeper experimental snow (Mörsdorf et al. 2019).

Greater $\mathrm{N}$ in leaves has previously been linked to enhanced concentration of labile $\mathrm{N}$ in the soil (Walsh et al. 1997; Welker et al. 2005; Semenchuk et al. 2015; Mörsdorf et al. 2019). The latter two studies followed plant $\mathrm{N}$ from mid (July 20 and 14, respectively) to end (September 14 and 2, respectively) of the growing season and discovered a clear decreasing trend throughout the entire period.

Our leaf nutrient data do not relate to our soil N, but this could simply, and most likely, be a matter of timing as the Late regime represents a one-month delay in the seasonal dynamics of soil and plant nutrients compared with that of Early, and so we are likely comparing different phenological stages reached on the same sampling date. A thorough sampling of both soils and leaves throughout the season would clarify these patterns.

Values of $\delta^{15} \mathrm{~N}$ followed a similar pattern to those of nitrogen, with higher values in Late in B. vivipara and S. polaris leaves, whereas the other species did not differ. We can compare our results to those of Mörsdorf et al. (2019). In our case, B. vivipara varied between $-4.8 \%$ in Early and $-2.7 \%$ in Late, whereas S. polaris varied between $-4.7 \%$ in Early and $-1.4 \%$ o in Late. In Mörsdorf et al. (2019) snow deposition altered $\delta^{15} \mathrm{~N}$ in B. vivipara from 5.1\% in Ambient to $-2.3 \%$ in Deep, and in S. polaris from $-5.3 \%$ to $-3.8 \%$. In short, both species had a larger concentration of ${ }^{15} \mathrm{~N}$ in enhanced snow conditions. Enhanced soil $\mathrm{N}$ availability has been linked on the regional and the global scale to an increment in plant $\delta^{15} \mathrm{~N}$ (Michelsen et al. 1998; Craine et al. 2009). Soil nitrogen pools have different content of ${ }^{15} \mathrm{~N}$ as a result of discrimination during microbial decomposition, which leads to a higher proportion of ${ }^{15} \mathrm{~N}$ in inorganic than in organic nitrogen compounds (Michelsen et al. 1996; Nadelhoffer et al. 1996; Yano et al. 2010). Competition between species can result, then, in different values 
of $\delta^{15} \mathrm{~N}$ (Nadelhoffer et al. 1996). A higher availability of $\mathrm{N}$ compounds may reduce that competition and even out $\delta^{15} \mathrm{~N}$ values between species.

Our values of $\delta^{15} \mathrm{~N}$ in B. vivipara and $S$. polaris have, therefore, two possible interpretations: either the availability of nitrogen compounds in the soil was higher in Late, or these species depended more strongly on inorganic $\mathrm{N}$ in Late. The first interpretation links back to our explanation in the discussion of soil characteristics: soil $\mathrm{N}$ may have been higher due to the longer snow-cover period, but by the time of sampling this excess was no longer present in the soil. The second interpretation suggests that some distinct aspect of the Late regime leads these plants to use inorganic $\mathrm{N}$ : either the environmental conditions (elevated soil moisture and $\mathrm{pH}$ ) or biotic relations (competition for nutrients against Equisetum arvense and (or) Eriophorum scheuchzeri). In future studies sampling soil throughout the season would help determine whether soil nutrients vary with snowmelt date, and measuring plant biomass and nutrient concentration at the different snow regimes could help link soil and plant nutrient dynamics.

\section{Species presence and NDVI}

As hypothesized (Hypothesis 2), natural Early and Late melting areas differed in the species present. Although a greater snow depth, warmer winter, and subsequently moister soils may enhance growing conditions for some species (Leffler et al. 2013; Blok et al. 2015; Addis and Bret-Harte 2019), it may also be detrimental for others, as the growing season becomes shorter and the timing of physiological events shifts the phenology (Scott and Rouse 1995; Walker et al. 1999; Semenchuk et al. 2016a).

Deeper snow with later melt and a shorter growing season has a strong effect on dwarf shrubs, which decline both in vegetative and reproductive performance (Rixen et al. 2010; Mallik et al. 2011), e.g., D. octopetala had reduced number of flowers and viable seeds under deep winter snow with later melt-out (Cooper et al. 2011). Experimentally increased snow reduced the cover of all live dwarf shrubs (Cooper et al. 2019). Dryas octopetala is a typical well-drained ridge species (Rønning 1965; Koroleva 2015) and was generally not present in our Late regime, in contrast to $S$. polaris (Fig. 6, Supplementary Table $S 5^{2}$ ), that has been found to tolerate very short growing seasons (Callaghan et al. 1993; Owczarek and Opala 2016), but may be sensitive to extremely waterlogged soil in early spring (Crawford 1996). However, in this pilot study we only have presence data rather than biomass or cover, thus limiting our understanding of species habitat preference.

The Late regime was characterized by the presence of Equisetum arvense and Eriophorum scheuchzeri. Late plots were located on the sides of gullies, which have a higher water input from snowmelt at the start of the growing season. This is reflected in the soil moisture content, with values twice as high in Late than in Early, and would explain the presence of Equisetum arvense and Eriophorum scheuchzeri, as these species are commonly distributed in many moist and wet environments, where they sometimes achieve dominance (Svalbard Flora 2020). Furthermore, Eriophorum scheuchzeri grows mainly on calcareous ground (Svalbard Flora 2020), where soil pH is relatively alkaline, as is the case in our study (Fig. 4B).

The mid-season NDVI values were highest in our Late regime, supporting our hypothesis 3, and relate to higher leaf nutrient content and potentially greater growth, as well as earlier phenological stage: plants in Late were at or close to their peak of growing season, whereas those in Early and Mid had already passed it. This is similar to data shown by Anderson et al. (2016) and Kankaanpää et al. (2018) where different plant communities had their peak NDVI at different dates, partly due to differing snow depth and melt-out dates (Walker et al. 1999). To get a deeper understanding of the effects of snowmelt on NDVI we should further study the variation in NDVI throughout the growing season, and 
more carefully consider the links between snowmelt time, NDVI and topography (Riihimäki et al. 2017).

Microtopography leads to variation in snow cover, snowmelt timing, species composition and phenology across the landscape. Plants of species occurring in all three snow melt regimes experience delayed phenology in Late compared with Early and Mid. Such differences in phenology within a small region can be important at the ecosystem level, as it suggests that a spatial mosaic of tundra patches enter their peak growing season at different dates. These patches of tundra gradually become suitable for utilization by herbivores, such as the Svalbard reindeer in our study site. This enables grazers to access nutritious forage throughout a longer period, following this "greening wave". Any major decreases in snow cover may therefore lead to a reduction in spatial heterogeneity (as shown by Niittynen Heikkinen and Luoto 2020), with consequences throughout the trophic levels.

Comparison of our natural topographic gradient with the nearby snow manipulation experiment (Cooper et al 2019; Mörsdorf et al 2019) is useful as it puts the experiment into a realistic perspective. The comparison of studies also underlines the importance of understanding whole-season nutrient dynamics, rather than just getting one mid-season value. Together, both approaches consistently demonstrate the importance of snow for species composition, nutrient dynamics, and growth, as well as indicating the role of a spatial mosaic of phenological development within the landscape for herbivores.

\section{Conclusion}

This pilot study demonstrated clear differences in plant species composition (presence), soil moisture, $\mathrm{pH}$, leaf nutrients and NDVI in the various snow regimes. Soil nutrient concentrations did not differ between snowmelt regimes.

Our results showed that:

1. Late snowmelt regimes with deeper snow had wetter soils, higher $\mathrm{pH}$, and the leaves of Bistorta vivipara and Salix polaris had higher concentrations of nutrients (nitrogen and $\delta^{15} \mathrm{~N}$ ). Higher leaf nutrient content of the most dominant plant species in Late regime could be attributed to an earlier phenological stage than plants occurring in the Mid and Early regimes.

2. Late snowmelt regime (snowbed) had the highest NDVI values, whereas those of Early and Mid snowmelt regimes were similar. This is most likely due to the higher nutrient content in leaves, leading to greater growth of the most common distributed plant species in the Late snowmelt regime.

3. Vegetation composition differed between Early and Late snowmelt regimes, with Dryas octopetala and Luzula arcuata characterizing the former and Equisetum arvense and Eriophorum scheuchzeri the latter.

4. Trends of increased nutrients with increased snow and later melt-out found in this study were similar to those observed by a nearby snow manipulation experiment carried out the same summer.

We recommend further studies in areas of differing snowmelt across the landscape to sample moisture, nutrients, and NDVI throughout the season and link this to detailed studies of plant composition.

Microtopography and, thus, snow distribution and timing of snowmelt, clearly play an important role in determining patchiness in plant community distribution, species composition and spatial and temporal mosaics of plant nutrient and developmental phenology, thereby contributing to landscape scale environmental heterogeneity. 


\section{Funding statement}

Funding for this project came from the Norwegian Research Council ("SnoEco" project, number 230970) and FRAM Centre Terrestrial Framework (project: "Summer's End"), both to EJC.

\section{Contributors' statement}

This study was designed by EJC and LN. Data analysis was carried out by MMA. Interpretation and manuscript preparation by MMA, EJC, and LN.

\section{Data availability statement}

Data are stored at UiT open access and are available from https://doi.org/10.18710/ C9XWRD.

\section{Acknowledgements}

We thank H.B. Anderson and A.M. Vik for field sampling, and N.S. Baggesen and P.L. Ambus for preparation of material for chemical analysis.

\section{References}

Addis, C.E., and Bret-Harte, M.S. 2019. The importance of secondary growth to plant responses to snow in the arctic. Functional Ecol, 33(6): 1050-1066. doi: 10.1111/1365-2435.13323.

Anderson, H.B., Nilsen, L., Tømmervik, H., Karlsen, S.R., Nagai, S., and Cooper, E.J. 2016. Using ordinary digital cameras in place of near-infrared sensors to derive vegetation indices for phenology studies of High Arctic vegetation. Remote Sensing, 8(10): 847. doi: 10.3390/rs8100847.

Aurela, M., Laurila, T., and Tuovinen, J.P. 2004. The timing of snow melt controls the annual $\mathrm{CO}_{2}$ balance in a subarctic fen. Geophysical Research Letters, 31(16): L16119. doi: 10.1029/2004GL020315.

Bardgett, R.D., van der Wal, R., Jónsdóttir, I.S., Quirk, H., and Dutton, S. 2007. Temporal variability in plant and soil nitrogen pools in a high-Arctic ecosystem. Soil Biol Biochemistry, 39(8): 2129-2137. doi: 10.1016/ j.soilbio.2007.03.016.

Blok, D., Weijers, S., Welker, J.M., Cooper, E.J., Michelsen, A., Löffler, J., and Elberling, B. 2015. Deepened winter snow increases stem growth and alters stem $\delta^{13} \mathrm{C}$ and $\delta^{15} \mathrm{~N}$ in evergreen dwarf shrub Cassiope tetragona in higharctic Svalbard tundra. Environ Res Lett, 10(4): 044008. doi: 10.1088/1748-9326/10/4/044008.

Brooks, P.D., Grogan, P., Templer, P.H., Groffman, P., Öquist, M.G., and Schimel, J. 2011. Carbon and nitrogen cycling in snow-covered environments. Geogr Compass, 5(9): 682-699. doi: 10.1111/j.1749-8198.2011.00420.x.

Buckeridge, K.M., and Grogan, P. 2008. Deepened snow alters soil microbial nutrient limitations in arctic birch hummock tundra. Appl Soil Ecol, 39(2): 210-222. doi: 10.1016/j.apsoil.2007.12.010.

Buckeridge, K.M., and Grogan, P. 2010. Deepened snow increases late thaw biogeochemical pulses in mesic low arctic tundra. Biogeochemistry, 101(1): 105-121. doi: 10.1007/s10533-010-9426-5.

Callaghan, T.V., Sømme, L., and Sonesson, M. 1993. Impacts of climate change at high latitudes on terrestrial plants and invertebrates. Research Report for the Directorate for Nature Management Nr. 1993-1. Directorate for Nature Management (DN), Trondheim.

Callaghan, T.V., Johansson, M., Brown, R.D., Groisman, P.Y., Labba, N., Radionov, V., et al. 2011. Multiple effects of changes in Arctic snow cover. Ambio, 40(S1): 32-45. doi: 10.1007/s13280-011-0213-x.

Clarke, K.R., and Warwick, R.M. 1994. An approach to statistical analysis and interpretation. Change Marine Communities, 2: 117-143.

Cooper, E.J. 2004. Out of sight, out of mind: thermal acclimation of root respiration in Arctic Ranunculus. Arctic Antarctic Alpine Res, 36(3): 308-313. doi: 10.1657/1523-0430(2004)036[0308:OOSOOM]2.0.CO;2.

Cooper, E.J., Dullinger, S., and Semenchuk, P. 2011. Late snowmelt delays plant development and results in lower reproductive success in the High Arctic. Plant Sci, 180(1): 157-167. doi: 10.1016/j.plantsci.2010.09.005.

Cooper, E.J., Little, C.J., Pilsbacher, A.K., and Mörsdorf, M.A. 2019. Disappearing green: Shrubs decline and bryophytes increase with nine years of increased snow accumulation in the High Arctic. J Vegetation Sci, 30(5): 857-867. doi: 10.1111/jvs.12793.

Craine, J.M., Elmore, A.J., Aidar, M.P., Bustamante, M., Dawson, T.E., Hobbie, E.A., et al. 2009. Global patterns of foliar nitrogen isotopes and their relationships with climate, mycorrhizal fungi, foliar nutrient concentrations, and nitrogen availability. New Phytologist, 183(4): 980-992. doi: 10.1111/j.1469-8137.2009.02917.x.

Crawford, R.M. 1996. Whole plant adaptations to fluctuating water tables. Folia Geobotanica, 31(1): 7-24. doi: 10.1007/BF02803990.

Darrouzet-Nardi, A., Steltzer, H., Sullivan, P.F., Segal, A., Koltz, A.M., Livensperger, C., et al. 2019. Limited effects of early snowmelt on plants, decomposers, and soil nutrients in Arctic tundra soils. Ecol Evolution, 9(4): 1820-1844. doi: 10.1002/ece3.4870. 
DeMarco, J., Mack, M.C., and Bret-Harte, M.S. 2011. The effects of snow, soil microenvironment, and soil organic matter quality on $\mathrm{N}$ availability in three Alaskan arctic plant communities. Ecosystems, 14(5): 804-817. doi: 10.1007/s10021-011-9447-5.

Elvebakk, A. 2005. A vegetation map of Svalbard on the scale 1: 3.5 mill. Phytocoenologia, 35(4): 951-967. doi: 10.1127/0340-269X/2005/0035-0951.

Eskelinen, A., Stark, S., and Männistö, M. 2009. Links between plant community composition, soil organic matter quality and microbial communities in contrasting tundra habitats. Oecologia, 161(1): 113-123. doi: 10.1007/ s00442-009-1362-5.

Evans, B.M., Walker, D.A., Benson, C.S., Nordstrand, E.A., and Petersen, G.W. 1989. Spatial interrelationships between terrain, snow distribution and vegetation patterns at an arctic foothills site in Alaska. Ecography, 12(3): 270-278. doi: 10.1111/j.1600-0587.1989.tb00846.x.

Gamon, J.A., Huemmrich, K.F., Stone, R.S., and Tweedie, C.E. 2013. Spatial and temporal variation in primary productivity (NDVI) of coastal Alaskan tundra: Decreased vegetation growth following earlier snowmelt. Remote Sensing Environ, 129: 144-153. doi: 10.1016/j.rse.2012.10.030.

Gasarch, E.I., and Seastedt, T.R. 2015. The consequences of multiple resource shifts on the productivity and composition of alpine tundra communities: inferences from a long-term snow and nutrient manipulation experiment. Plant Ecol Diversity, 8(5): 751-761. doi: 10.1080/17550874.2015.1123319.

Giesler, R., Högberg, M., and Högberg, P. 1998. Soil chemistry and plants in Fennoscandian boreal forest as exemplified by a local gradient. Ecology, 79(1): 119-137. doi: 10.1890/0012-9658(1998)079[0119:SCAPIF]2.0.CO;2.

Gillespie, M.A., Baggesen, N., and Cooper, E.J. 2016. High Arctic flowering phenology and plant-pollinator interactions in response to delayed snow melt and simulated warming. Environ Res Lett, 11(11): 115006. doi: 10.1088/ 1748-9326/11/11/115006.

Grogan, P., Michelsen, A., Ambus, P., and Jonasson, S. 2004. Freeze-thaw regime effects on carbon and nitrogen dynamics in sub-arctic heath tundra mesocosms. Soil Biol Biochemistry, 36(4): 641-654. doi: 10.1016/ j.soilbio.2003.12.007.

Hobbie, J.E., and Hobbie, E.A. 2006. ${ }^{15} \mathrm{~N}$ in symbiotic fungi and plants estimates nitrogen and carbon flux rates in Arctic tundra. Ecology, 87(4): 816-822. doi: 10.1890/0012-9658(2006)87[816:NISFAP]2.0.CO;2.

Hoegh-Guldberg, O., Jacob, D., Taylor, M., Bindi, M., Brown, S., Camilloni, I., et al. 2018. Chapter 3: Impacts of 1.5 C global warming on natural and human systems. In Intergovernmental Panel on Climate Change (IPCC) special report on the impacts of global warming of $1.5^{\circ} \mathrm{C}$ above pre-industrial levels and related global greenhouse gas emission pathways, in the context of strengthening the global response to the threat of climate change, sustainable development, and efforts to eradicate poverty. World Meteorological Organization, Geneva, Switzerland. International Plant Names Index (IPNI). 2020. Available from https://www.ipni.org/ [accessed 24 June 2020].

Jia, G.J., Epstein, H.E., and Walker, D.A. 2004. Controls over intra-seasonal dynamics of AVHRR NDVI for the Arctic tundra in northern Alaska. Int J Remote Sensing, 25(9): 1547-1564. doi: 10.1080/0143116021000023925.

Jonasson, S., Michelsen, A., and Schmidt, I.K. 1999. Coupling of nutrient cycling and carbon dynamics in the Arctic, integration of soil microbial and plant processes. Appl Soil Ecol, 11(2-3): 135-146. doi: 10.1016/S09291393(98)00145-0.

Jordan, C.F. 1969. Derivation of leaf-area index from quality of light on the forest floor. Ecology, 50(4): 663-666. doi: $10.2307 / 1936256$.

Kane, D.L., Hinzman, L.D., Benson, C.S., and Liston, G.E. 1991. Snow hydrology of a headwater Arctic basin: 1. Physical measurements and process studies. Water Resource Res, 27(6): 1099-1109. doi: 10.1029/91WR00262.

Kankaanpää, T., Skov, K., Abrego, N., Lund, M., Schmidt, N.M., and Roslin, T. 2018. Spatiotemporal snowmelt patterns within a high Arctic landscape, with implications for flora and fauna. Arctic Antarctic Alpine Res, 50(1): e1415624. doi: 10.1080/15230430.2017.1415624.

Koller, E.K., and Phoenix, G.K. 2017. Seasonal dynamics of soil and plant nutrients at three environmentally contrasting sites along a sub-Arctic catchment sequence. Polar Biol, 40(9): 1821-1834. doi: 10.1007/s00300-017-2105-4.

Koroleva, N.E. 2015. Survey of Dryas octopetala-dominated plant communities in the European and NorthWest-Siberian Arctic. Botanica Pacifica: J Plant Science Conservation, 4(1): 17-36. doi: 10.17581/bp.2015.04102.

Kreyling, J., Beierkuhnlein, C., Pritsch, K., Schloter, M., and Jentsch, A. 2008. Recurrent soil freeze-thaw cycles enhance grassland productivity. New Phytologist, 177(4): 938-945. doi: 10.1111/j.1469-8137.2007.02309.x.

Laidler, G.J., Treitz, P.M., and Atkinson, D.M. 2008. Remote sensing of arctic vegetation: relations between the NDVI, spatial resolution and vegetation cover on Boothia Peninsula, Nunavut. Arctic, 61(1): 1-13. doi: 10.14430/ arctic2.

Lambert, A.M., Miller-Rushing, A.J., and Inouye, D.W. 2010. Changes in snowmelt date and summer precipitation affect the flowering phenology of Erythronium grandiflorum (glacier lily; Liliaceae). Am J Botany, 97(9): 1431-1437. doi: 10.3732/ajb.1000095.

Larsen, K.S., Grogan, P., Jonasson, S., and Michelsen, A. 2007. Respiration and microbial dynamics in two subarctic ecosystems during winter and spring thaw: effects of increased snow depth. Arctic Antarctic Alpine Res, 39(2): 268-276. doi: 10.1657/1523-0430(2007)39[268:RAMDIT]2.0.CO;2.

Leffler, A.J., and Welker, J.M. 2013. Long-term increases in snow pack elevate leaf $\mathrm{N}$ and photosynthesis in Salix arctica: responses to a snow fence experiment in the High Arctic of NW Greenland. Environ Res Lett, 8(2): 025023. doi: $10.1088 / 1748-9326 / 8 / 2 / 025023$.

Lipson, D.A., and Monson, R.K. 1998. Plant-microbe competition for soil amino acids in the alpine tundra: effects of freeze-thaw and dry-rewet events. Oecologia, 113(3): 406-414. doi: 10.1007/s004420050393. 
Lipson, D.A., Zona, D., Raab, T.K., Bozzolo, F., Mauritz, M., and Oechel, W.C. 2012. Water-table height and microtopography control biogeochemical cycling in an Arctic coastal tundra ecosystem. Biogeosciences, 9(1): 577-591. doi: 10.5194/bg-9-577-2012.

Liston, G.E., and Sturm, M. 1998. A snow-transport model for complex terrain. J Glaciol, 44(148): 498-516. doi: 10.1017/S0022143000002021.

Liu, J., Curry, J.A., Wang, H., Song, M., and Horton, R.M. 2012. Impact of declining Arctic sea ice on winter snowfall. Proc Natl Acad Sci, 109(11): 4074-4079. doi: 10.1073/pnas.1114910109

Mallik, A.U., Wdowiak, J.V., and Cooper, E.J. 2011. Growth and reproductive responses of Cassiope tetragona, a circumpolar evergreen shrub, to experimentally delayed snowmelt. Arctic Antarctic Alpine Res, 43(3): 404-409. doi: 10.1657/1938-4246-43.3.404.

Michelsen, A., Schmidt, I.K., Jonasson, S., Quarmby, C., and Sleep, D. 1996. Leaf ${ }^{15} \mathrm{~N}$ abundance of subarctic plants provides field evidence that ericoid, ectomycorrhizal and non-and arbuscular mycorrhizal species access different sources of soil nitrogen. Oecologia, 105(1): 53-63. doi: 10.1007/BF00328791.

Michelsen, A., Quarmby, C., Sleep, D., and Jonasson, S. 1998. Vascular plant ${ }^{15} \mathrm{~N}$ natural abundance in heath and forest tundra ecosystems is closely correlated with presence and type of mycorrhizal fungi in roots. Oecologia, 115(3): 406-418. doi: 10.1007/s004420050535.

Mikan, C.J., Schimel, J.P., and Doyle, A.P. 2002. Temperature controls of microbial respiration in arctic tundra soils above and below freezing. Soil Biol Biochemistry, 34(11): 1785-1795. doi: 10.1016/S0038-0717(02)00168-2.

Morgner, E., Elberling, B., Strebel, D., and Cooper, E.J. 2010. The importance of winter in annual ecosystem respiration in the High Arctic: effects of snow depth in two vegetation types. Polar Res, 29(1): 58-74. doi: 10.1111/j.17518369.2010.00151.x.

Mörsdorf, M.A., Baggesen, N.S., Yoccoz, N.G., Michelsen, A., Elberling, B., Ambus, P.L., and Cooper, E.J. 2019. Deepened winter snow significantly influences the availability and forms of nitrogen taken up by plants in High Arctic tundra. Soil Biol Biochemistry, 135: 222-234. doi: 10.1016/j.soilbio.2019.05.009.

Myneni, R.B., Hall, F.G., Sellers, P.J., and Marshak, A.L. 1995. The interpretation of spectral vegetation indexes. IEEE Transactions on Geosci and Remote Sensing, 33(2): 481-486. doi: 10.1109/TGRS.1995.8746029.

Nadelhoffer, K., Shaver, G., Fry, B., Giblin, A., Johnson, L., and McKane, R. 1996. ${ }^{15} \mathrm{~N}$ natural abundances and N use by tundra plants. Oecologia 107(3): 386-394. doi: 10.1007/BF00328456.

Niittynen, P., Heikkinen, R., and Luoto, M. 2018. Snow cover is a neglected driver of Arctic biodiversity loss. Nature Climate Change, 8(11): 997-1001. doi: 10.1038/s41558-018-0311-x.

Niittynen, P., Heikkinen, R., and Luoto, M. 2020. Decreasing snow cover alters functional composition and diversity of Arctic tundra. Proc Natl Acad Sci, 117(35): 21480-21487. doi: 10.1073/pnas.2001254117.

Niittynen, P., and Luoto, M. 2018. The importance of snow in species distribution models of arctic vegetation. Ecography, 41(6): 1024-1037. doi: 10.1111/ecog.03348.

Nobrega, S., and Grogan, P. 2007. Deeper snow enhances winter respiration from both plant-associated and bulk soil carbon pools in birch hummock tundra. Ecosystems, 10(3): 419-431. doi: 10.1007/s10021-007-9033-z.

Norwegian Centre for Climate Services 2019. Klimaprofil Longyearbyen/Climate profile of Longyearbyen. Available from https://cms.met.no/site/2/klimaservicesenteret/klimaprofiler/klimaprofil-longyearbyen/_attachment/14742? ts $=16 \mathrm{a} 0 \mathrm{bec} 6 \mathrm{e} 90$.

Oksanen, J., Blanchet, F.G., Friendly, M., Kindt, R., Legendre, P., McGlinn, D., et al. 2018. vegan: Community Ecology Package. R package version 2.5-3. Available from https://CRAN.R-project.org/package=vegan.

Owczarek, P., and Opała, M. 2016. Dendrochronology and extreme pointer years in the tree-ring record (AD 19512011) of polar willow from southwestern Spitsbergen (Svalbard, Norway). Geochronometria, 43(1): 84-95. doi: 10.1515/geochr-2015-0035.

Park, J.S., Son, D., Lee, Y.K., Yun, J.H., and Lee, E.J. 2018. Multivariate relationships between snowmelt and plant distributions in the High Arctic tundra. J Plant Biol, 61(1): 33-39. doi: 10.1007/s12374-017-0361-z.

Pattison, R.R., and Welker, J.M. 2014. Differential ecophysiological response of deciduous shrubs and a graminoid to long-term experimental snow reductions and additions in moist acidic tundra, Northern Alaska. Oecologia, 174(2): 339-350. doi: 10.1007/s00442-013-2777-6.

Pinheiro, J., Bates, D., DebRoy, S., Sarkar, D., and R Core Team 2019. nlme: Linear and Nonlinear Mixed Effects Models. R package version 3.1-140. Available from https://CRAN.R-project.org/package=nlme.

$\mathrm{R}$ Core Team 2019. R: A language and environment for statistical computing. R Foundation for Statistical Computing, Vienna, Austria. Available from https://www.R-project.org/.

Riihimäki, H., Heiskanen, J., and Luoto, M. 2017. The effect of topography on arctic-alpine aboveground biomass and NDVI patterns. Int J Appl Earth Observation Geoinfo, 56: 44-53. doi: 10.1016/j.jag.2016.11.005.

Rixen, C., Schwoerer, C., and Wipf, S. 2010. Winter climate change at different temporal scales in Vaccinium myrtillus, an Arctic and alpine dwarf shrub. Polar Res, 29(1): 85-94. doi: 10.1111/j.1751-8369.2010.00155.x.

Rumpf, S.B., Semenchuk, P.R., Dullinger, S., and Cooper, E.J. 2014. Idiosyncratic responses of high arctic plants to changing snow regimes. PLoS ONE, 9(2): e86281. doi: 10.1371/journal.pone.0086281.

Rønning, O.I. 1965. Studies in Dryadion of Svalbard. Norsk Polarinstitutt Skrifter, 134.

Saha, S.K., Rinke, A., and Dethloff, K. 2006. Future winter extreme temperature and precipitation events in the Arctic. Geophys Res Lett, 33(15). doi: 10.1029/2006GL026451.

Schimel, J.P., and Bennett, J. 2004. Nitrogen mineralization: challenges of a changing paradigm. Ecology, 85(3): 591-602. doi: 10.1890/03-8002. 
Schimel, J.P., Bilbrough, C., and Welker, J.M. 2004. Increased snow depth affects microbial activity and nitrogen mineralization in two Arctic tundra communities. Soil Biol Biochemistry, 36(2): 217-227. doi: 10.1016/ j.soilbio.2003.09.008.

Scott, P.A., and Rouse, W.R. 1995. Impacts of increased winter snow cover on upland tundra vegetation: a case example. Climate Res, 5(1): 25-30. doi: 10.3354/cr005025.

Semenchuk, P.R., Elberling, B., Amtorp, C., Winkler, J., Rumpf, S., Michelsen, A., and Cooper, E.J. 2015. Deeper snow alters soil nutrient availability and leaf nutrient status in high Arctic tundra. Biogeochemistry, 124(1): 81-94. doi: 10.1007/s10533-015-0082-7.

Semenchuk, P.R., Gillespie, M.A., Rumpf, S.B., Baggesen, N., Elberling, B., and Cooper, E.J. 2016a. High Arctic plant phenology is determined by snowmelt patterns but duration of phenological periods is fixed: An example of periodicity. Environ Res Lett, 11(12): 125006. doi: 10.1088/1748-9326/11/12/125006.

Semenchuk, P.R., Christiansen, C.T., Grogan, P., Elberling, B., and Cooper, E.J. 2016b. Long-term experimentally deepened snow decreases growing-season respiration in a low- and high-arctic tundra ecosystem. J Geophys Res: Biogeosci, 121(5): 1236-1248. doi: 10.1002/2015JG003251.

Sharma, S., Szele, Z., Schilling, R., Munch, J.C., and Schloter, M. 2006. Influence of freeze-thaw stress on the structure and function of microbial communities and denitrifying populations in soil. Appl Environ Microbiol, 72(3): 2148-2154. doi: 10.1128/AEM.72.3.2148-2154.2006.

Siciliano, S.D., Palmer, A.S., Winsley, T., Lamb, E., Bissett, A., Brown, M.V., et al. 2014. Soil fertility is associated with fungal and bacterial richness, whereas $\mathrm{pH}$ is associated with community composition in polar soil microbial communities. Soil Biol Biochemistry, 78: 10-20. doi: 10.1016/j.soilbio.2014.07.005.

Stark, S., Männistö, M.K., and Eskelinen, A. 2014. Nutrient availability and pH jointly constrain microbial extracellular enzyme activities in nutrient-poor tundra soils. Plant Soil, 383(1): 373-385. doi: 10.1007/s11104-014-2181-y.

Strebel, D., Elberling, B., Morgner, E., Knicker, H.E., and Cooper, E.J. 2010. Cold-season soil respiration in response to grazing and warming in High-Arctic Svalbard. Polar Res, 29(1): 46-57. doi: 10.1111/j.1751-8369.2010.00154.x.

Svalbard Flora. 2020. Vascular plants in Svalbard - The flora of Svalbard. Available from https://svalbardflora.no/ [accessed 24 June 2020].

Tolgensbakk, J., Soerbel, L., and Hoegvard, K. 2000. Adventdalen, geomorphological and quaternary geological map, Svalbard 1:100,000, Spitsbergen sheet C9Q. Norsk Polarinstitutt Temakart, 32.

Tucker, C.J. 1979. Red, and photographic infrared linear combinations for monitoring vegetation. Remote Sens. Environ, 8: 127-150. doi: 10.1016/0034-4257(79)90013-0.

Xu, L., Myneni, R.B., Chapin III, F.S., Callaghan, T.V., Pinzon,, J.E., Tucker,, C.J., et al. 2013. Temperature and vegetation seasonality diminishment over northern lands. Nature Climate Change, 3(6): 581-586. doi: 10.1038/ nclimate1836.

Walker, D. A., Binnian, E., Evans, B. M., Lederer, N. D., Nordstrand, E., and Webber, P. J. 1989. Terrain, vegetation, and landscape evolution of the R4D research site, Brooks Range Foothills, Alaska. Ecography, 12(3): $238-261$. doi: 10.1111/j.1600-0587.1989.tb00844.X.

Walker, M.D., Walker, D.A., Welker, J.M., Arft, A.M., Bardsley, T., Brooks, P.D., et al. 1999. Long-term experimental manipulation of winter snow regime and summer temperature in arctic and alpine tundra. Hydrological Processes, 13(14): 2315-2330. doi: 10.1002/(SICI)1099-1085(199910)13:14/15<2315::AID-HYP888>3.0.CO;2-A.

Walsh, N.E., McCabe, T.R., Welker, J.M., and Parsons, A.N. 1997. Experimental manipulations of snow-depth: effects on nutrient content of caribou forage. Global Change Biol, 3(S1): 158-164. doi: 10.1111/j.1365-2486.1997.gcb142.x.

Welker, J.M., Fahnestock, J.T., Sullivan, P.F., and Chimner, R.A. 2005. Leaf mineral nutrition of Arctic plants in response to warming and deeper snow in northern Alaska. Oikos, 109(1): 167-177. doi: 10.1111/j.00301299.2005.13264.X.

Yano, Y., Shaver, G.R., Giblin, A.E., and Rastetter, E.B. 2010. Depleted ${ }^{15} \mathrm{~N}$ in hydrolysable-N of arctic soils and its implication for mycorrhizal fungi-plant interaction. Biogeochemistry, 97(2): 183-194. doi: 10.1007/s10533-0099365-1.

Zhang, Z., Kane, D.L., and Hinzman, L.D. 2000. Development and application of a spatially-distributed Arctic hydrological and thermal process model (ARHYTHM). Hydrol Processes, 14(6): 1017-1044. doi: 10.1002/(SICI)10991085(20000430)14:6<1017::AID-HYP982>3.0.CO;2-G.

Zhang, T., Wang, N.F., Liu, H.Y., Zhang, Y.Q., and Yu, L.Y. 2016. Soil pH is a key determinant of soil fungal community composition in the Ny-Ålesund Region, Svalbard (High Arctic). Front Microbiol, 7: 227. doi: 10.3389/ fmicb.2016.00227.

Zinger, L., Shahnavaz, B., Baptist, F., Geremia, R.A., and Choler, P. 2009. Microbial diversity in alpine tundra soils correlates with snow cover dynamics. ISME J, 3(7): 850-859. doi: 10.1038/ismej.2009.20. 